\title{
Causes and Characteristics of Peri-Orbital Contusions and Their Relationship with Intracranial Injuries in Inward Patients in Two Tertiary Care Hospitals in Sri Lanka
}

\author{
Warushahennadi J ${ }^{1 *}$, Senavirathne $\mathrm{AS}^{2}$, Godakandage $\mathrm{SSP}^{3}$, Pathirana $\mathrm{MD}^{4}$, Jayarathne $\mathrm{UGB}^{5}$, Ambepitiya $\mathrm{SGH}^{2}$ \\ ${ }^{1}$ Department of Forensic Medicine, Faculty of Medicine, University of Ruhuna, Sri Lanka, ${ }^{2}$ Office of the Judicial \\ Medical Officer, District General Hospital, Matara, Sri Lanka, ${ }^{3}$ Family Health Bureau, Sri Lanka, ${ }^{4}$ National \\ Hospital of Sri Lanka, ${ }^{5}$ Office of the Judicial Medical Officer, Teaching Hospital, Karapitiya, Sri Lanka
}

\begin{abstract}
Introduction: The peri-orbital contusion (PC) is a common injury in day to day surgical casualties. It is a common injury observed in patients who are in an unconscious state following head injuries. The aim of the study is to describe characteristics of PC and understand its relationship with associated injuries, especially with facial injuries and intracranial injuries.
\end{abstract}

Methods: This retrospective study reviewed the medico-legal examination forms (MLEF) of 67 inward patients in Teaching Hospital, Karapitiya and District General Hospital, Matara with peri-orbital contusions following trauma during a period of six months from January 2020 to June 2020.

Results: A total number of 67 patients were included with $81 \%$ being male patients. The commonest soft tissue injuries around the PCs were abrasions $(\mathrm{n}=39,71 \%)$ and $25(38 \%)$ of the study sample had fractures of the skull. The majority $(n=22,88 \%)$ of them had fractures of facial bones followed by vault and basal skull fractures. The majority of PCs $(45 \%)$ were blue in colour and only $8 \%$ were red. The red colour was observed only in PCs of less than 24 hours. The main cause for PC was due to direct blow to the eye while the rest $(n=29,45 \%)$ were due to the indirect blow. A higher incidence of fracture of the head was observed in assaults (39\%).

Conclusions: The commonest cause for the black eye in the study sample was the direct blow with a blunt force in an assault. The red colour was observed in PC of less than 24 hours duration. The PC had not caused major injuries to the eye but there was frequent involvement of facial bone fractures.

Keywords: Peri-orbital contusion, causes, associated injuries

Received: 22 Nov 2020, Revised version accepted: 28 Dec 2020, Published: 31 Dec 2020. *Corresponding author: Warushahennadi J, $\triangle$ email: janakiwh@gmail.com (D) ORCID: https://orcid.org/0000-0002-6880-5513

Cite this article as: Warushahennadi J, Senavirathne AS, Godakandage SSP et al. Causes and Characteristics of Peri-Orbital Contusions and Their Relationship with Intracranial Injuries in Inward Patients in Two Tertiary Care Hospitals in Sri Lanka. Medico-Legal Journal of Sri Lanka. 2020;8(2):23-27, DOI: http://dx.doi.org/10.4038/mljsl.v8i2.7421

Copyright: @ 2019 with the Medico-legal Journal of Sri Lanka.

This is an open-access article distributed under the terms of the Creative Commons Attribution 4.0 International License, which permits unrestricted use, distribution, and reproduction in any medium provided the original author and source are credited.

\section{Introduction}

A black eye or peri-orbital contusion (PC) is the appearance of bruising around the eyes and is caused by blood tracking along the tissue planes into periorbital tissues causing discolouration in the upper and lower eyelids. ${ }^{[1]}$ The PC can be unilateral or bilateral and the latter is called 'Raccoon's eye. ${ }^{[2]}$ The black eye is usually caused by a direct impact on the eye socket, which may or may not be associated with injuries on the skin on the upper cheek, eyebrow, nose or other parts of the face ${ }^{[3]}$ Another cause of black eye following trauma is the gravitational seepage of blood beneath the scalp from an injury on or above the eyebrow. A third cause of the black eye following trauma, which is usually bilateral, is due to the percolation of blood into the orbit from a fracture of the anterior cranial fossa of the skull. ${ }^{[4,5]}$ The peri-orbital contusions may 
be associated with other injuries such as injuries to the eye, fractures of the facial bones, and intracranial haemorrhages ${ }^{[6]}$ endangering the life of the person.

However, PC may rarely occur in a number of nontraumatic diseases such as migraine, neuroblastoma, amyloidosis, and increased intracranial pressure and is also associated with multiple myeloma. There are reported cases of developing PC following sinus surgeries and rhinoplasty. ${ }^{[7]}$

There can be different injuries associated with traumatic PC, which include soft tissue injuries around the orbits, facial or skull fractures and intracranial injuries. The colour of peri-orbital contusions changes with time, which helps for the dating of the injury. Standard textbooks give quite precise times for contusions appearing red or purple in the first 2 days, green from 4 to 7 days, and yellow from 7 to 10 days, with resolution between 14 to 30 days. ${ }^{[8,9]}$

The peri-orbital contusion is a common injury in day-to-day surgical casualties. Also, it is a common injury observed in patients who are in an unconscious state following head injuries. Therefore it is important to understand the relationship between features of peri-orbital contusions and intracranial injuries.

The aim of the study is to describe characteristics of PC and understand its relationship with associated injuries, especially with facial injuries and intracranial injuries.

\section{Methodology}

This retrospective study was conducted at the Teaching Hospital Karapitiya and District General Hospital, Matara, which are the main tertiary health care facilities in the Southern Province of Sri Lanka. The authors reviewed the medico-legal examination forms where the medico-legal examinations were done on patients with peri-orbital contusions following trauma during a period of six months from January 2020. Unconscious patients at the time of medico-legal examination, patients who could not recall the event were excluded from the study.

A pre-tested questionnaire was used to collect necessary data from the medico-legal examination forms of convenient samples. Data were entered into a database created using SPSS statistical software (version 20) and analyzed. Chi-square and Fisher's Exact Tests were used to assessing the association between variables.

\section{Results}

A total number of 67 patients were included in the study with $81 \%$ being male patients. The majority $(42,63 \%)$ were adults in the age group of $18-60$ years, followed by elderly people above 60 years $(16,24 \%)$ and children less than 18 years $(9,13 \%)$.

While $8(12 \%)$ had bilateral PC, $41 \%$ and $47 \%$ had it only around the right eye or left eye respectively. The medico legal examination of the patients was performed at different time intervals from the time of infliction of injury. Out of the total, $30 \%$ were examined within 24 hours of the incident, $44 \%$ and $15 \%$ were examined within $24-48$ and longer than 72 hours after the incident respectively.

Different soft tissue injuries around the orbits were observed in $55(82 \%)$ of the participants and the commonest injury was abrasions (39, 71\%), followed by lacerations $(29,53 \%)$, and cuts $(9$, $16 \%)$. It was observed that $25(37 \%)$ of the study sample had fractures of the skull. The majority of them (88\%) had fractures of facial bones followed by vault and basal skull fractures (Fig. 1)

\section{Types of skull fracture}

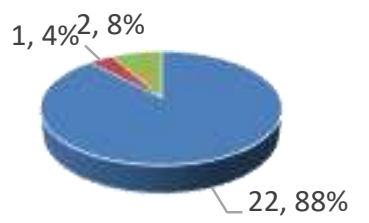

\section{- Facial " Basal n Vault}

Figure 01. Incidence of types of skull fractures

The involvement of the eyes is common in traumatic PCs. The subconjunctival haemorrhage was present in $51(76 \%)$ of patients. When the impairment of the vision was concerned $19(28 \%)$ had complained of impaired of the vision and out of them 15 (79\%) were diagnosed to have temporary impairment of the vision and $3(16 \%)$ were having a permanent impairment of the vision. The causes for the permanent impairment of the vision was hyphema in 2 incidences and possible post-traumatic cataract in one incidence. When the associated intracranial injuries were concerned $4(6 \%)$ had intracranial haemorrhages.

Considering the $\mathrm{PC}$ and the associated injuries on the head, the category of hurt was determined according to the Penal Code of Sri Lanka. The majority (41, $61 \%$ ) were non-grievous hurt followed by grievous 
hurt $(23,34 \%)$ and Fatal in the Ordinary Cause of Nature $(3 \%)$.

The colour of the PC was observed during the medico-legal examination. The majority $(45 \%)$ were blue in colour and only $8 \%$ were red. The colour of the $\mathrm{PC}$ was compared with the time interval between the incident and the examination of the patient. It was revealed that the red colour was observed only in the PC of less than 24 hours.

According to Table 01, the blue, purple and black colour contusions around the eye were observed even when the time interval between the incident and the examination was less than 24 hours.

Table 01. The Time interval between incident and examination of the study subjects by their colour around the orbit

\begin{tabular}{|c|c|c|c|c|c|c|}
\hline $\begin{array}{l}\text { Гime } \\
\text { nterval } \\
\text { yetween } \\
\text { ncident } \\
\text { and } \\
\text { examinatio } \\
\text { n }\end{array}$ & $\begin{array}{r}\text { Red } \\
\text { n(\%) }\end{array}$ & $\begin{array}{r}\text { Blue } \\
\text { n }(\%)\end{array}$ & $\begin{array}{r}\text { Purple } \\
\text { n }(\%)\end{array}$ & $\begin{array}{l}\text { Black } \\
\text { n }(\%)\end{array}$ & $\begin{array}{r}\text { No } \\
\text { chang } \\
\mathrm{e} \\
\mathrm{n}(\%)\end{array}$ & $\begin{array}{l}\text { Total } \\
\mathbf{N} \%\end{array}$ \\
\hline$<24$ Hrs. & $05(25)$ & $11(55)$ & $03(15)$ & $01(05)$ & $00(00)$ & $20(100)$ \\
\hline $24-48 \mathrm{Hrs}$ & $00(00)$ & $18(62)$ & $08(28)$ & $02(07)$ & $01(03)$ & $29(100)$ \\
\hline 48-72 Hrs & $00(00)$ & $00(00)$ & $05(71)$ & $02(29)$ & $00(00)$ & 07 (100) \\
\hline$>72$ Hrs. & $00(00)$ & $00(00)$ & $00(00)$ & $10(100)$ & $00(00)$ & $10(100)$ \\
\hline Total & 05 & 29 & 16 & 15 & 01 & 66 \\
\hline
\end{tabular}

When the causes of injury were concerned 35 (55\%) participants sustained PC due to direct blow to the eye while the rest $(29,45 \%)$ were due to the indirect blow, which suggests impact to the forehead or scalp area of the head.

Table 02. Distribution of the cause of injury of subjects by category of hurt

\begin{tabular}{|c|c|c|c|c|c|}
\hline $\begin{array}{l}\text { Category } \\
\text { of hurt } \\
\text { Cause of } \\
\text { injury } \\
N=64\end{array}$ & $\begin{array}{l}\text { Non- } \\
\text { grievo } \\
\text { us hurt } \\
\text { n }(\%)\end{array}$ & $\begin{array}{l}\text { Grievo } \\
\text { us } \\
\text { Hurt } \\
\text { n }(\%)\end{array}$ & $\begin{array}{l}\text { FIOCN } \\
\text { n }(\%)\end{array}$ & $\begin{array}{l}\text { Total } \\
\text { n }(\%)\end{array}$ & p value \\
\hline Direct & $22(63)$ & $12(34)$ & $01(03)$ & $35(100)$ & \\
\hline Indirect & $17(59)$ & $11(38)$ & $01(04)$ & $29(100)$ & 0.897 \\
\hline
\end{tabular}

Indirect blows were more associated with grievous hurt $(38 \%)$ and FIOCN (3\%) compared with direct blows (34\% and 3\% respectively). However, these differences were not statistically significant $(\mathrm{p}=0.897)$ (Table 2).

The assaults, traffic accidents, and non-traffic accidents were the different manners of infliction of PC. The majority $28(42 \%)$ sustained PC following an assault and $24(36 \%)$ and $14(21 \%)$ were following traffic accident and accidental injury respectively. The assailant was a known person in $80 \%$ of victims following assaults.

Table 03. Distribution of the manner of injury of subjects by the incidence of fracture of head

\begin{tabular}{|c|c|c|c|c|c|}
\hline \multirow{2}{*}{$\begin{array}{l}\text { Manner } \\
\text { injury } \\
(\mathrm{N}=66)\end{array}$} & \multicolumn{3}{|c|}{ Fracture of the head } & \multirow[b]{2}{*}{$\begin{array}{c}\chi^{2} \\
\text { value }\end{array}$} & \multirow[b]{2}{*}{$\begin{array}{c}p \\
\text { value }\end{array}$} \\
\hline & $\begin{array}{l}\text { Yes } \\
\mathrm{n}(\%)\end{array}$ & $\begin{array}{l}\text { No } \\
\mathrm{n}(\%)\end{array}$ & $\begin{array}{l}\text { Total } \\
\mathrm{n}(\%)\end{array}$ & & \\
\hline Assault & $11(39)$ & $17(61)$ & $28(100)$ & & \\
\hline $\begin{array}{l}\text { Non-traffic } \\
\text { accident }\end{array}$ & $05(36)$ & 09 (64) & $14(100)$ & & \\
\hline RTA* & $09(37)$ & $15(62)$ & $24(100)$ & 0.053 & 0.974 \\
\hline
\end{tabular}

*Road Traffic Accident

According to Table 03, a higher incidence of fracture of the head was observed in assaults $(40 \%)$. It was least seen in non-traffic accidents (36\%). However, these differences are not statistically significant $(\mathrm{p}=0.974)$.

Table 04. Distribution of the type of injury of subjects by the incidence of Subconjunctival haemorrhage

\begin{tabular}{|c|c|c|c|c|}
\hline \multirow{2}{*}{$\begin{array}{l}\text { Type of } \\
\text { injury }(n=67)\end{array}$} & \multicolumn{3}{|c|}{ Subconjunctival haemorrhage } & \multirow[b]{2}{*}{$\begin{array}{c}p \\
\text { value* }\end{array}$} \\
\hline & $\begin{array}{l}\text { Yes } \\
\mathrm{n}(\%)\end{array}$ & $\begin{array}{l}\text { No } \\
\mathrm{n}(\%)\end{array}$ & $\begin{array}{l}\text { Total } \\
\mathrm{n}(\%)\end{array}$ & \\
\hline \multicolumn{5}{|l|}{ Category of hurt } \\
\hline $\begin{array}{l}\text { Non- } \\
\text { grievous }\end{array}$ & $29(71)$ & $12(29)$ & $41(100)$ & \\
\hline Grievous & $19(83)$ & $04(17)$ & $23(100)$ & \\
\hline FIOCN & $3(100)$ & $00(00)$ & $03(100)$ & 0.396 \\
\hline \multicolumn{5}{|c|}{ Intracranial injuries } \\
\hline Yes & $04(100)$ & $00(00)$ & $04(100)$ & \\
\hline No & $47(75)$ & $16(25)$ & $63(100)$ & 0.565 \\
\hline
\end{tabular}

Fatal in the ordinary cause of nature (FIOCN) was always (100\%) associated with subconjunctival haemorrhage. A lesser but high incidence of subconjunctival haemorrhage was seen in grievous (83\%) and non-grievous hurt (71\%). All (100\%) of those who had sustained intracranial injuries presented with subconjunctival haemorrhage, as against $75 \%$ who had not sustained intracranial injuries. However, all these differences were not statistically significant ( $\mathrm{p}>0.05$ ). (Table 04).

\section{Discussion}

A black eye is an appearance of bruising around the eyes. It is a frequent clinical feature after traumatic injuries to the head and neck, including basal skull fractures, soft tissue injuries, and convexity fractures ${ }^{[1]}$ The skin of the eyelids is not thick and there is only a thin layer of connective tissue between the skin and the underlying muscle layer. This loose 
layer of connective tissue is where accumulation of fluid, such as blood collects following an injury. ${ }^{[10]}$.

It is not difficult to differentiate a fresh bruise from an older one from the gross examination. ${ }^{[1]}$ According to the available literature and standard textbooks the contusions appear red, blue or purple within 24 hours, green from 4 to 7 days, yellow from 7 to 10 days with a resolution between 14 to 30 days.[8,11] The present study also showed similar findings. An important finding of this study was that the red colour PC could be observed around the eyes only within 24 hours. However, the other colours of contusions, i.e. blue, purple and black which are described in the literature were also observed in PC in all time ranges between the incident and the examination. This finding implies that only red colour in the peri-orbital area can be used to determine the time interval of less than 24 hours between the incident and the examination, but the finding may depend on the skin colour of the victim.

Involvement of the eye and facial bone fractures are common in PCs. In this study sample $76 \%$ had a subconjunctival haemorrhage, the majority had temporary impairment of the vision, only a few had permanent impairment of the vision and $88 \%$ of the fractures were involved with the facial bones. The findings imply that the traumatic PC had not caused major injury to the eye, although there was frequent incidence of facial bone fractures. These findings were compatible with the retrospective analysis conducted on patients with minor head trauma with PCs identified that $68 \%$ of the patients with PC had an underlying fracture. ${ }^{[12]}$ The fatal in the ordinary cause of nature category was always (100\%) associated with subconjunctival haemorrhage and the grievous hurt category was also associated with lesser but higher incidence of subconjunctival haemorrhage. This indicates that PCs associated with subconjunctival haemorrhage should be carefully investigated. According to the study, direct blow to the eye by a known person was the commonest cause for the PC. The injuries on the head due to assault were mainly non-grievous in nature than more severe categories of hurt.

The study shows that the commonest manner of infliction of PC was assaults followed by traffic accidents and non-traffic accidents. Similar type of study done on 189 patients who were examined for ophthalmological evaluation following peri-orbital trauma revealed that the major causes were falls followed by motor vehicle accidents and assaults. ${ }^{[13]}$

\section{Conclusion}

The commonest cause for the black eye in the study sample was the direct blow with a blunt force in an assault. The red colour was observed in Peri-orbital Contusion of less than 24 hours duration. The PC had not caused major injuries to the eye but there was frequent involvement of facial bone fractures. The subconjunctival haemorrhage was the associated injury in more severe categories of hurt indicating it should be carefully investigated.

\section{Limitations}

Unconscious patients with severe head injuries were not included in this study. Therefore, characteristics of PC in severe head injury patients may be different from the findings in the present study.

\section{Disclosure statement}

Conflicts of interest: The authors declare that they have no conflicts of interest.

Funding: None

\section{References}

1. Somasundaram A, Laxton AW, Perrin RG. The clinical features of peri-orbital ecchymosis in a series of trauma patients. Injury. 2014 Jan; 45(1):203-5.

2. Nasiri J, Zamani F, Peri-orbital Ecchimosis (Raccon`s Eye) and Orbital Hematoma following Endoscopic Retrograde Cholangiopancreatography. Case Rep Gastroenterol. 2017;11(1):134-41. DOI: $10.1159 / 000456657$

3. Knight B, Saukko PJ. Knight's Forensic Pathology. 4th Edition.London. Arnold. 2004.

4. Fernando AMH, Mudo M, Delmonti C, Braga FM, Grande JCD. Raccon`s Eyes' (peri-orbital haematoma) as a sign of skull base fracture. Injury. 2001 Dec. Volume 32, Issue 10, Pages 745-47.

5. Mc Pheeters RA, White S, Winter A. Raccon Eyes. West J Emerg Med. 2010;11 (1):97

6. Roth FS, Koshy JC, Goldberg JS, Soparker CN. Pearls of orbital trauma management. Semin Plast Surg. 2010;24(4):398-410. DOI:10.1055/s0030-1269769.

7. Arjaj AM. The use of nasal packing post rhinoplasty: does it increase peri-orbital ecchymosis? A prospective study. Al arfaj journal of Otolaryngology - Head and Neck Surgery. 2015;44(22). DOI: 10.1186/s40463015-0075-5.

8. Byard RW, Langlois NE. Bruises. "The more we know, the less we understand?". Forensic Sci. Med Pathology. 2015;11(4):479-81 
9. Polson CL, Gee DJ, Knight B. The essentials of forensic medicine. 4th ed. Oxford: Pegamon press, 1985:91-147

10. Drake DRL, Vogl W, Mitchell AWM Gray H. Gray`s Anatomy for Students. 2nd edition. Philadelphia Churchill Livingstone. Elsevier. 2010

11. Vanesis P. Interpretation of Bruises at autopsy. J Clin Pathol. 2001;54(5):348-55

12. Buttner M, Schlittler FL, Michel C, Exadaktylos AK, Lizuka t. Is a black eye a useful sign of facial fractures in patients with minor head injuries? A retrospective analysis in a level I trauma cantre over 10 years. Br J Oral Maxillofac Surg. 2014; 52(6):518-22. DOI: 10.1016/j.bjoms. 2014.03. 018.

13. Chang HYP, Huynh N, Gerogiannis SB. Eye injuries associated with orbital or peri-orbital trauma. ARVO Annual Meeting Abstract. 2012;53(14):4962 